\title{
WATER MITE SPECIES OF THE GENUS PROTZIA PIERSIG, 1896 (ACARI, HYDRACHNIDIA, HYDRYPHANTIDAE) OF RUSSIA
}

\author{
Petr V. Tuzovsky
}

\author{
Papanin Institute for Biology of Inland Waters, Russian Academy of Sciences, Borok, Yaroslavl \\ Region, Russia \\ e-mail: tpv@ibiw.ru
}

\begin{abstract}
This study presents a detailed taxonomic review of water mites of the genus Protzia Piersig, 1896 (Acari, Hydryphantidae) found in Russia. In particular, the illustrations and descriptions of six Protzia species are provided: $P$. buryatica sp. n., P. caucasica (Sokolow, 1927), P. eximia (Protz, 1896), P. primoryensis sp.n., P. rotunda Walter, 1908) and P. uralensis sp.n.
\end{abstract}

KEY WORDS: Water mites, Hydryphantidae, Protziinae, Protzia, morphology, new species, identification key, Russia.

DOI: 10.21684/0132-8077-2021-29-1-67-80

\section{INTRODUCTION}

The following Protzia species were recorded from the former USSR Russia: $P$. cabardinica Sokolow, 1940, P. caucasica Sokolow, 1927, P. elongata Sokolow, 1927 and P. eximia (Protz, 1896) (Sokolow 1940). The taxonomic status of some of these remains unclear. In particular, Gerecke (1996b) regarded $P$. elongata as a junior synonym of $P$. caucasica, and Pešić (2005) synonymized $P$. cabardinica with $P$. rotunda.

The aim of this paper is to present the descriptions of the males and females of the Protzia species collected in Russia and to provide an identification key for the adults.

\section{MATERIALS AND METHODS}

Specimens were collected in the fluvial waters of the European and the Asian parts of Russia. Most specimens were not dissected, thus preserving the natural shape of the body. For several females and males, gnathosoma and legs where mounted in a position that allowed the examination of the chelicerae, pedipalps and legs in a lateral view. All specimens were mounted in Hoyer's medium.

The following abbreviations are used throughout the article: $\mathrm{H}$ - height, L-length; $\mathrm{n}$ - number of specimens measured; P-1-5-pedipalp segments (trochanter, femur, genu, tibia and tarsus); Wwidth; I-IV-Leg-1-6 - first to fourth legs, segments 1-5 (trochanter, basifemur, telofemur, genu, tibia and tarsus).

All measurements are provided in micrometers $(\mu \mathrm{m})$. The lengths of the appendage segments are given as dorsal lengths. Protzia species do not exhibit external sexual dimorphism, but mature females are usually larger than males. The type material has been deposited in the collection of the
Papanin Institute for Biology of Inland Waters (Borok, Russia). The species were identified using the original descriptions and papers by Sokolow (1927, 1940), Gerecke (1996a, b) and Di Sabatino et al. (2010).

\section{SYSTEMATICS}

Family Hydryphantidae Piersig, 1896

Subfamily Protziinae Koenike, 1909

Genus Protzia Piersig, 1896

Diagnosis (refined after Gerecke 1996a; Di Sabatino et al. 2010). All species red or orange in color. Lateral eyes encapsulated. Frontal eye rudimentary and unpigmented or absent. Dorsal and postventral idiosoma without muscle attachment sclerites. Genital field with more than three, generally numerous, pairs of acetabula and genital setae. Acetabula generally on stalks, at least the posterior ones. Genital flaps developed as porose longish sclerite; or as narrow, lightly sclerotized bars; or completely absent. Legs without swimming setae. Leg claws with lateral clawlets, often arranged in the shape of a fan. Protzia species do not exhibit external sexual dimorphism, but mature females usually larger than males.

\section{Protzia buryatica sp.n.}

Figs. 1-12

Type material. Holotype: male, slide 9935, Asia, Russia, Buryatiya, Barguzin District, Maximikha River, $53^{\circ} 15^{\prime} 41^{\prime \prime} \mathrm{N} 108^{\circ} 44^{\prime} 29^{\prime \prime} \mathrm{E}$, depth $0.4 \mathrm{~m}$, ground stones, 8 August 2016, leg. V. Stolbov.

Diagnosis. Color red, frontal eye absent; genital flaps not developed, gonopore field smooth with $12-13$ pairs of acetabula and 15-20 pairs of setae, all genital acetabula roundish and subequal 


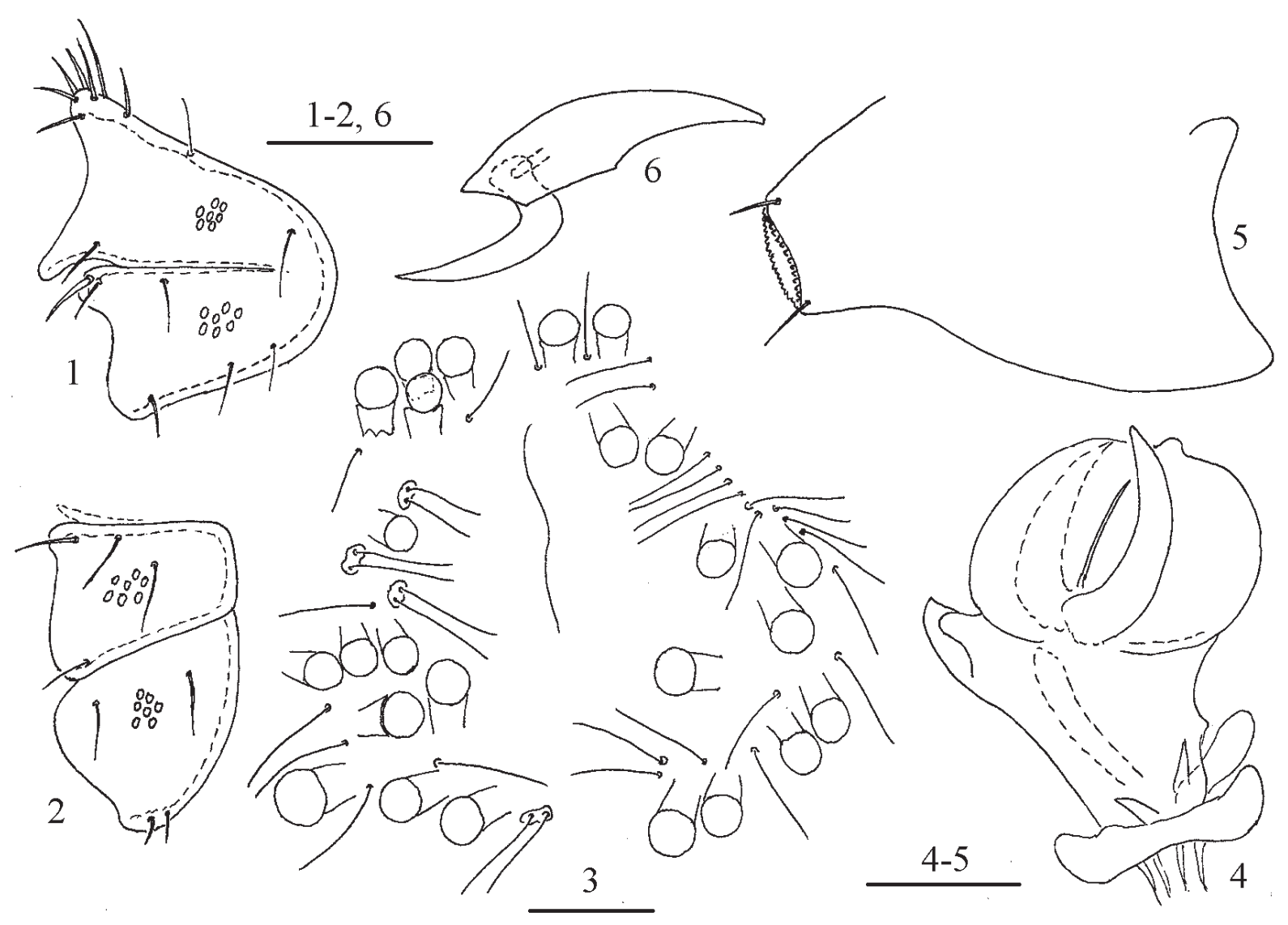

Figs. 1-6. Protzia buraytica sp.n., male: 1-coxal plates I+II; 2-coxal plates III+IV; 3 -genital field; 4 - ejaculatory complex; 5-capitulum, lateral view; 6-chelicera. Scale bars: 1-2, $6=100 \mu \mathrm{m} ; 3-5=50 \mu \mathrm{m}$.

in size; leg claws with 5-6 lateral and 11-13 medial clawlets.

Description. Male. Color red. Integument papillate, frontal eye not developed. Coxal plates I+II (Fig. 1) with rounded medial margin, coxal plate I with eight anterolateral setae, one medial and one posterolateral seta; coxal plate II with three anterior and three posterior setae. Suture line between coxal plates I+II incomplete, obliterated medially. Coxal plate III subrectangular, with straight medial margin and bearing four setae, coxal plate IV subtriangular, with two long anterior and two short posterior setae (Fig. 2). All coxal plates with circular or oval pores.

Genital field (Fig. 3) smooth, with 12-13 pairs of acetabula and 15-20 pairs of setae, scattered between acetabula; all acetabula roundish, subequal in size. Genital flaps not developed. Ejaculatory complex proximal chamber large, proximal arms massive pointed, broadest basally, tapering gradually to apex, distal arms slightly developed with obtuse tips (Fig. 4).

Capitulum dorso-ventrally elevated and with moderately long rostrum, mouth disk rather large
(Fig. 5). Chelicera (Fig. 6) basal segment moderately large, with equally convex dorsal margin, chela robust, basal segment/chela L 1.68.

Pedipalp stout (Fig. 7): P-1 with short dorsodistal seta; P-2 ventral margin short, almost straight, with four subequal dorsal setae and one long mediodistal seta; P-3 ventral margin slightly convex $(\mathrm{L} / \mathrm{H}$ ratio 1.1), with two dorsal setae; $\mathrm{P}-4$ longer than $\mathrm{P}-2$ (P-2/P-4 L 0.7) slightly tapering distally, with two unequal ventrodistal setae, one fine dorsodistal seta and thick pointed dorsodistal spine.

Legs very stout and densely covered with strong setae. The shape and the arrangement of setae on legs I-IV as shown in Figs. 8-11. Leg claws with 5-6 lateral and 11-13 medial clawlets (Fig. 12).

Measurements $(\mathrm{n}=1)$. Idiosoma about L 750; coxal plates 1+2 L 190, W 160; coxal plates 3+4 L 185, W 115; ejaculatory complex L 125; capitulum L 190, rostrum L 35; cheliceral segments: base L 165, chela L 95; acetabula L 18-20, acetabula stalks L 12-20; pedipalp segments (P-1-5) L: 26, 72, 57, 102, 24; leg segments L: I-Leg-1-6: 60, 100, 110, 120, 135, 135; II-Leg-1-6: 55, 85, 100, 


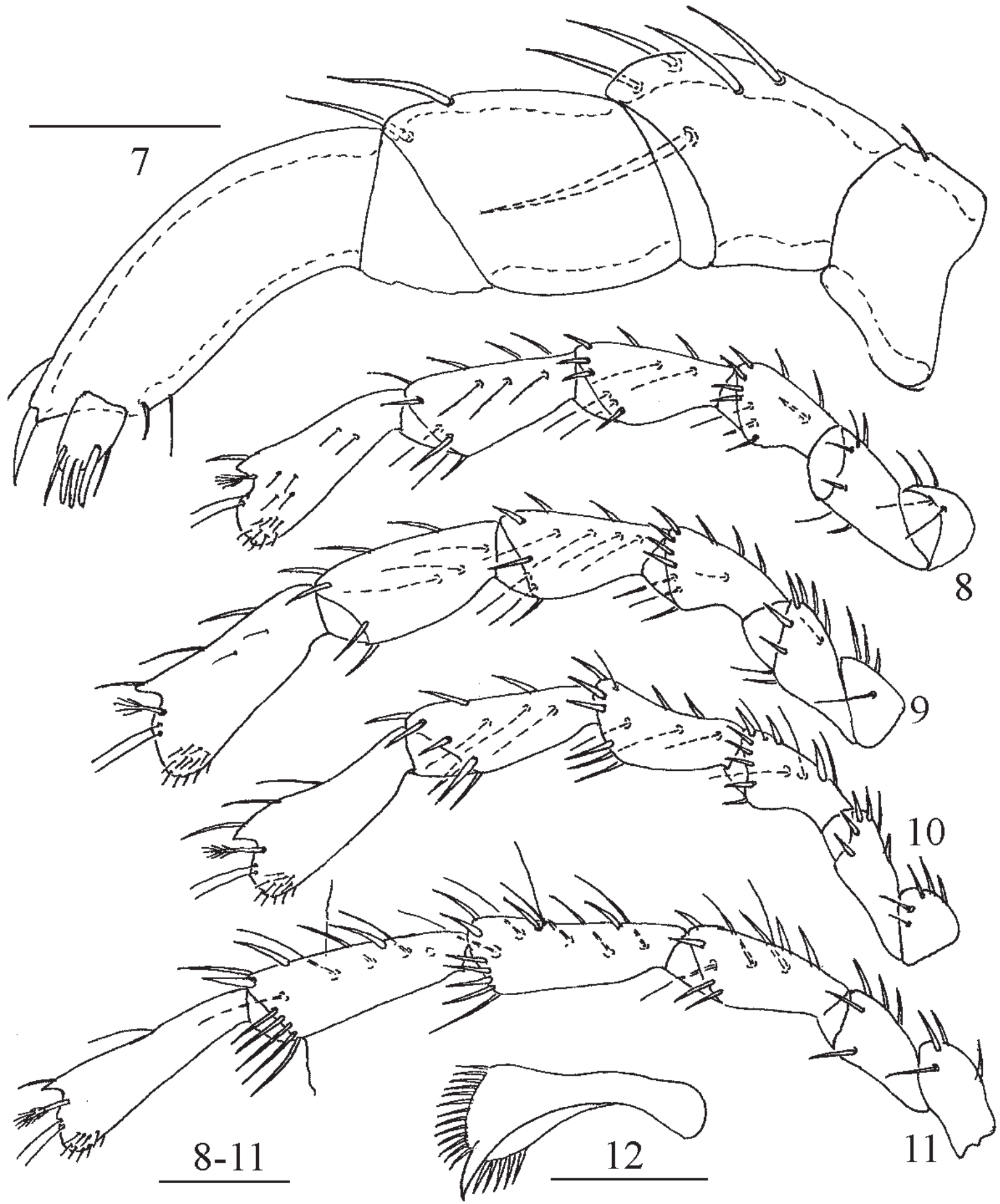

Figs. 7-12. Protzia buraytica sp.n., male: 7—pedipalp, 8-leg I, 9-leg II, 10-leg III, 11-leg IV, 12—claw of leg IV. Scale bars: $7,12=50 \mu \mathrm{m} ; 8-11=100 \mu \mathrm{m}$.

130, 150, 140; III-Leg-1-6: 50, 75, 110, 125, 150, 135; IV-Leg-1-6: 85, 80, 100, 175, 185, 160.

Female. Unknown.

Differential diagnosis. The present species is similar to Protzia felix Gerecke, 1996 in the shape of the coxal plates and the structure of the gnathosoma. Differences between the two species are found in the following characters (character states of $P$. felix given in parenthesis; data from Gerecke 1996b). Male: coxal plates I+II large, L/W 190/160 (comparatively small L/W 138-163/116-130); gonopore field smooth (with fine villi); acetabula large L/W 18-20/17-21 (relatively small, L/W 12-15/13-15); caudal stalks relatively long, 


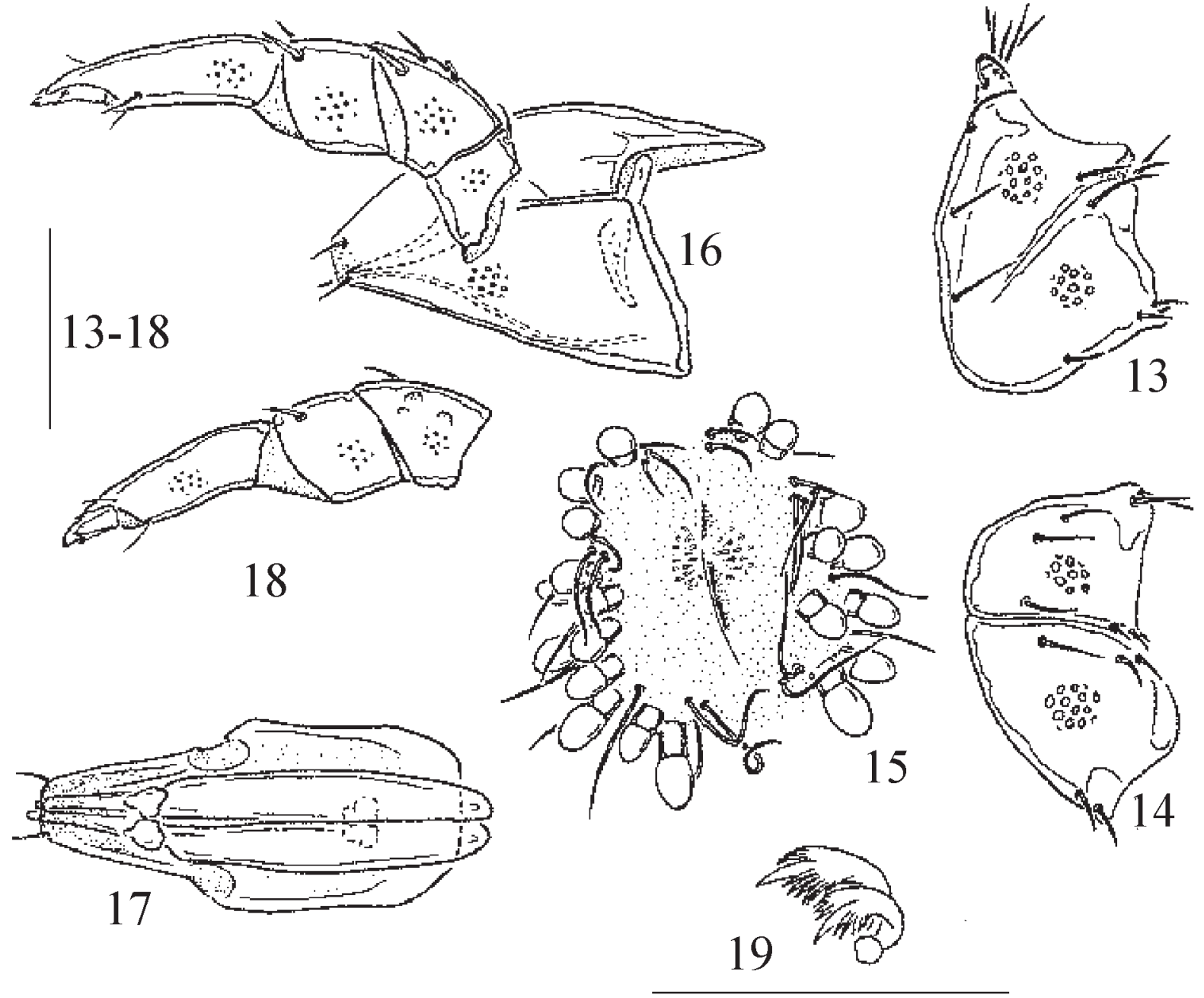

Figs. 13-19. Protzia caucasica Sokolow, 1927: 13-coxal plates I+II; 14-coxal plates III+IV; 15-genital field; 16-gnatosoma, lateral view; 17-gnatosoma, dorsal view; 18 - pedipalp, lateral view; 19-leg claw. Scale bars: $13-18,19=100 \mu \mathrm{m}$ (after Gerecke 1996a).

L 17-22 (comparatively short, L 6-10); P-2 mediodistal seta long (short); leg claws with 11-13 medial clawlets (with 7-9 medial clawlets).

Etymology. The species is named after the region (Buryatiya) where it was collected.

Habitat. Fluvial streams.

Distribution. Asia: Russia (Buryatiya).

\section{Protzia caucasica Sokolow, 1927}

Protzia elongata Sokolow, 1927

Figs. 13-19

I was unable to examine any specimens of $P$. caucasica. The diagnosis of this species is based on reference data (Sokolow 1927, 1940; Gerecke 1996a).

Diagnosis. Color red, frontal eye present, genital setae located on soft integument, genital field with 9-16 pairs of acetabula, caudal genital acetabula elongate, leg claws with 4-5 lateral and 7-8 medial clawlets.

Description. Both sexes. Color red. Frontal eye present. Coxal plate I with slightly convex medial margin and bearing 11 setae; coxal plate II with seven setae (Fig. 13). Medial margin of anterior coxal groups widely rounded or forming obtuse angle, posterior margin of coxal plate II almost straight. Suture line between coxal plates I+II incomplete, obliterated medially. Coxal plate III subrectangular, with straight or slightly convex medial margin, bearing seven setae (Fig. 14). Coxal plate IV subtriangular, with equally rounded medial margin and bearing five setae. Surface of all coxal plates with large pores. Genital field (Fig. 15) with 9-16 pairs of acetabula, anterior acetabula nearly roundish, posterior acetabula elongated, posterior acetabula and stalks larger than anterior 
ones, caudal stalks/caudal acetabula L 0.6 ; gonopore field with fine villi, genital flaps not developed.

Capitulum robust, with almost straight ventral (Fig. 16) and posterior margin (Fig. 17); rostrum long. Basal segment of chelicera large, chela relatively short, sickle-shaped; basal segment/chela L 2.0. Excretory pore unsclerotized.

Pedipalp stout (Figs. 16 and 18): P-1 with short dorsodistal seta; P-2 ventral margin short and straight, with two short subequal dorsal setae, mediodistal seta short and not reaching anterior half of P-3; P-3 ventral margin straight, length slightly larger than height ( $\mathrm{L} / \mathrm{H}$ ratio 1.1$)$, with two subequal dorsodistal setae; P-4 slender, with subparallel dorsal and ventral margin. Leg claws with 4-6 lateral and 6-8 medial clawlets (Fig. 19).

Male. Measurements. Idiosoma L 750-850, W about 540; capitulum L 200, chelicera L 253; genital field with 9-12 pairs of acetabula and 15-16 pairs of setae; I-IV-Leg L: 560, 575, 590, 720.

Female. Measurements. Idiosoma L about 750-850, W about 540; capitulum L 230-234, W 110, rostrum L 90; chelicera L 234, basal segment/ chela L 2.0; pedipalp segments pedipalp segments (P-1-5) L: 326; I-IV-Leg L: 580, 620, 670, 800.

Deutonymph. Genital field with three pairs of acetabula (Sokolow 1927, 1940).

Distribution. Europe: Russia, Turkey; Asia: Japan (Sokolow 1927, 1940; Imamura 1954; Gerecke 1996a).

\section{Protzia eximia (Protz, 1896)}

Figs. 20-31

I was unable to examine any specimens of P. eximia. The diagnosis of this species is based on reference data (Sokolow 1940; Gerecke 1996a; Di Sabatino 2010).

Diagnosis. Color red, frontal eye present, coxal plate I medial margin straight, genital setae located on soft integument, genital field with about 8-13 pairs of acetabula and 15-20 pairs of setae, anterior acetabula nearly roundish, posterior acetabula elongated, P-3 with single dorsodistal seta, leg claws with 4-5 lateral and 7-8 medial clawlets.

Description. Both sexes. Color red, small frontal eye present. Coxal plate I (Fig. 20) with straight medial margin bearing of eight setae; coxal plate II with four setae. Medial margin of anterior coxal groups roundish, posterior margin of coxal plate II slightly concave. Suture line between coxal plates almost I+II complete. Coxal plate III (Fig. 21) subrectangular, with convex medial margin, bearing five unequal setae. Coxal plate IV subtriangular, with equally rounded medial margin and bearing five unequal setae. Surface of all coxal plates with large pores. Genital field with 8-13 pairs of acetabula and 15-20 pairs of setae, anterior acetabula generally roundish, caudal ones elongated (L/W ratio 1.5). Acetabula stalks shorter than acetabula.

Capitulum (Figs. 23 and 24) dorsally elevated and with moderately long rostrum, posterior margin straight. Basal segment of chelicera (Fig. 25) large, with equally convex dorsal margin, chela robust (basal segment/chela L 1.8). Excretory pore unsclerotized.

Pedipalp relatively stout (Figs. 26 and 27): P-1 with short dorsodistal seta; P-2 ventral margin short, almost straight, with three subequal dorslateral setae and one comparatively short mediodistal seta; P-3 ventral margin straight or slightly convex and a little shorter than height $(\mathrm{L} / \mathrm{H}$ ratio $>1.0)$, with single dorsodistal seta; P-4 slender, slightly tapering distally, with four fine setae (L ratio P2/P-4 0.6). Leg claws with 4-5 lateral and 7-9 medial clawlets (Figs. 30 and 31).

Male. Gonopore field with fine villi (Fig. 22). Ejaculatory complex (Figs. 28 and 29) proximal chamber large with small anteromedian projection; proximal arms long, broadest basally, tapering gradually to apex; distal arms shorter than proximal arms.

Measurements. Idiosoma L/W 600-800/450 600; capitulum L 160, chelicera L 221, basal segments/chela L 1.8; ejaculatory complex L 125; pedipalp segments (P-1-5) L: 274; Legs I-IV L: $544,569,571,752$.

Female. Larger than male. Gonopore field smooth.

Measurements. Idiosoma L/W 700-1,100/500 800; capitulum L 190-220, rostrum about 70, chelicera L 250, chela 80.

Deutonymph. Genital field with three pairs of acetabula (Sokolow 1927, 1940).

Distribution. Probably, holoarctic. (Di Sabatino et al. 2010).

\section{Protzia primoryensis sp.n.}

Figs. 32-43

Type material. Holotype: male, slide 4946, Asia, Russia, Primorye Territory, Rudnaya River, 26 September 1984, leg. T.S. Vshivkova. Paratypes: 9 females and 1 male, same locality and data as holotype. 

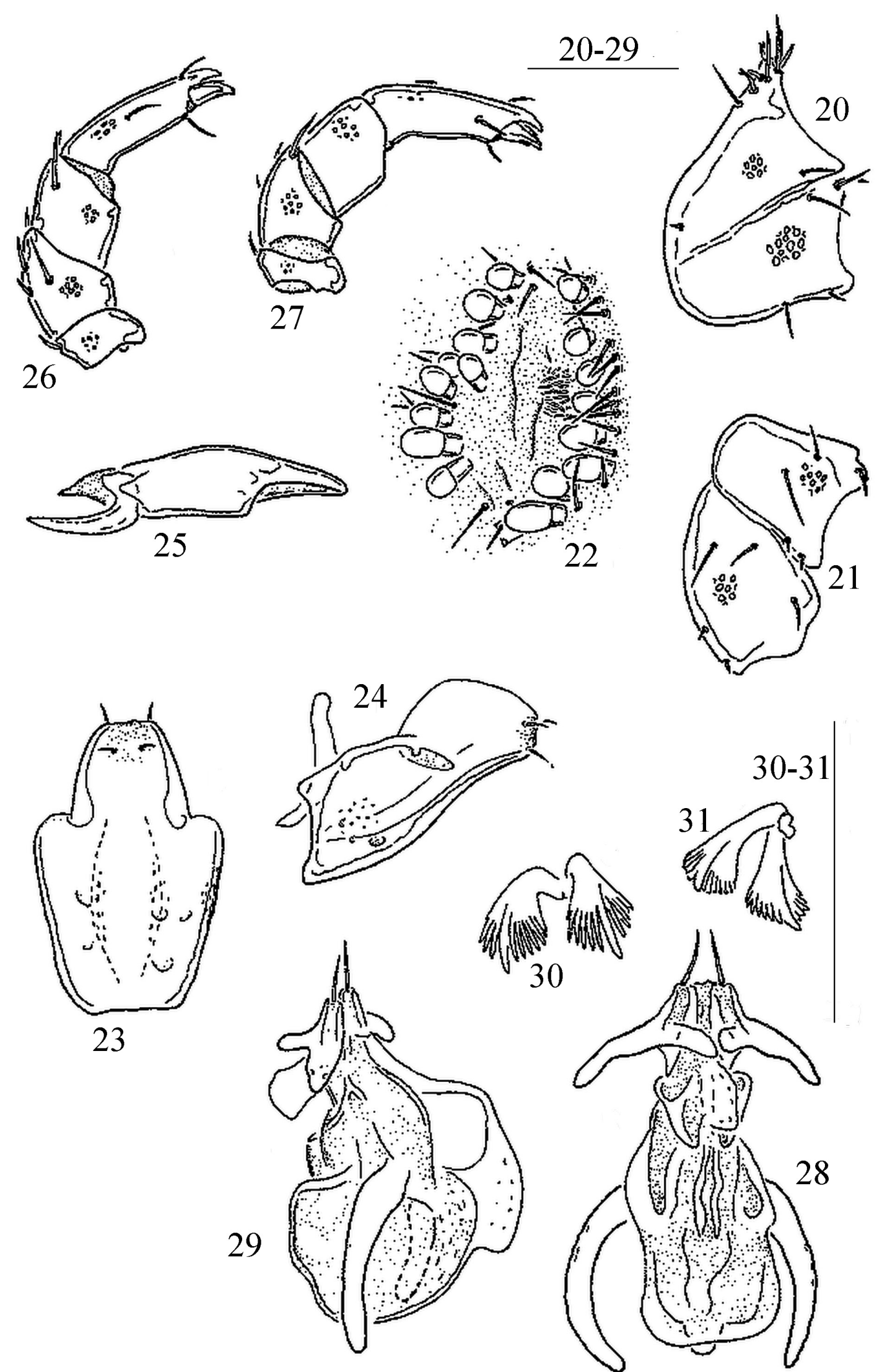

Figs. 20-31. Protzia eximia (Protz, 1896): 20 — coxal plates I+II; 21—coxal plates III+IV; 22—genital field; 23-24capitulum; 23-ventral view; 24-lateral view; 25-chelicerae; 26-27-pedipalp; 28-29-ejaculatory complex; 28-ventral view; 29-lateral view; 30-31-leg claws; 26-27-female; 20-25, 28-31-male. Scale bars: 20-29, $30-31=100 \mu \mathrm{m}$ (after Gerecke 1996a). 

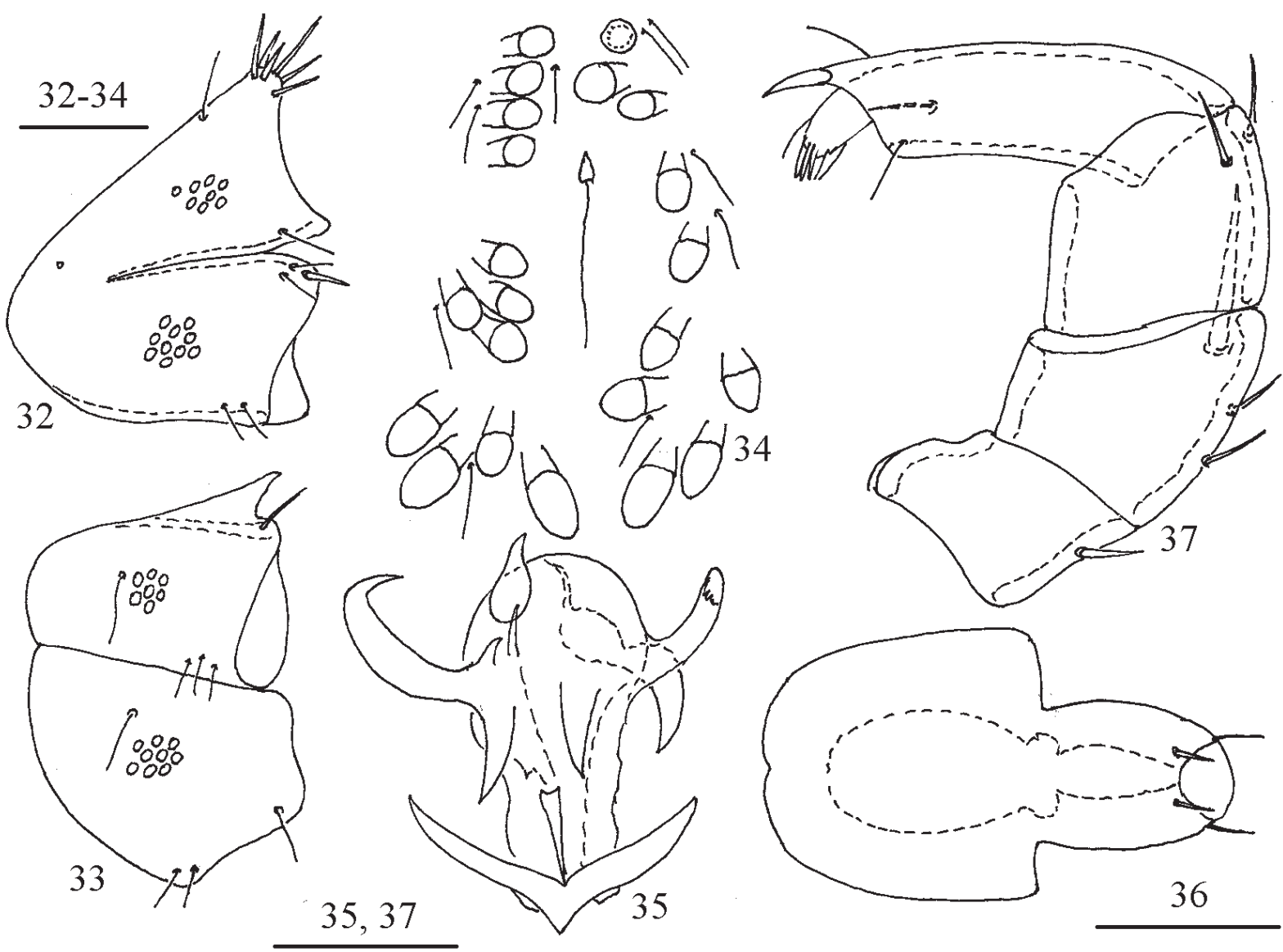

Figs. 32-37. Protzia primoryensis sp.n., male: 32 - coxal plates I+II; 33 - coxal plates III+IV; 34—genital field; 35ejaculatory complex; 36 - capitulum, lateral view; 37 - pedipalp. Scale bars: $32-34,35,37$ and $36=50 \mu \mathrm{m}$.

Diagnosis. Color red, frontal eye absent, coxal plate I medial margin straight, genital field with about $10-14$ pairs of acetabula and $4-15$ pairs of setae, genital setae located on soft integument, anterior acetabula nearly roundish, posterior acetabula elongated, P-2 with two short dorsal setae and one long mediodistal seta, P-3 with two dorsodistal seta, leg claws with 4-5 lateral and 7-8 medial clawlets.

Description. Both sexes. Color red, integument papillate, frontal eye not developed, dorsal and postventral idiosoma surface without muscle attachment sclerites. Anterior coxal groups (Fig. 32) with rounded medial margin. Coxal plates I with straight anterior margin, bearing nine setae: seven unequal anterolateral setae, one anteromedial and one posterolateral thin seta; coxal plate II posterior margin nearly straight with three unequal anterolateral and two thin subequal posterolateral setae. Suture line between coxal plates I+II incomplete, obliterated medially. Coxal plate III subrectangular, with slightly convex medial margin, bearing one thin medial seta, one comparatively thick anterolateral seta and three thin, short posterolateral setae; coxal plate IV subtriangular, with equally convex medial margin bearing one thin medial, one posterolateral seta and two posterior setae (Fig. 33). Genital field smooth, genital flaps not developed (Fig. 34). All acetabula on stalks, several of anterior acetabula almost roundish, caudal acetabula elongated.

Capitulum (Fig. 36) with moderately long rostrum, ventral setae a little shorter than dorsal ones. Basal segment of chelicera (Fig. 38) large, with equally convex dorsal margin, basal segment/ chela L 1.9-2.1.

Pedipalp stout (Fig. 37): P-1 with short dorsodistal seta; P-2 ventral margin short, straight, with two short dorsal setae and one long, thick mediodistal seta; P-3 ventral margin straight, with two short dorsodistal setae; P-4 slender, longer than P-2, with subparallel dorsal and ventral margins, bearing two ventrodistal setae, one fine dorsodistal seta and large thick pointed dorsodistal spine.

Legs very stout and densely covered with strong setae. Shape and arrangement of setae on 


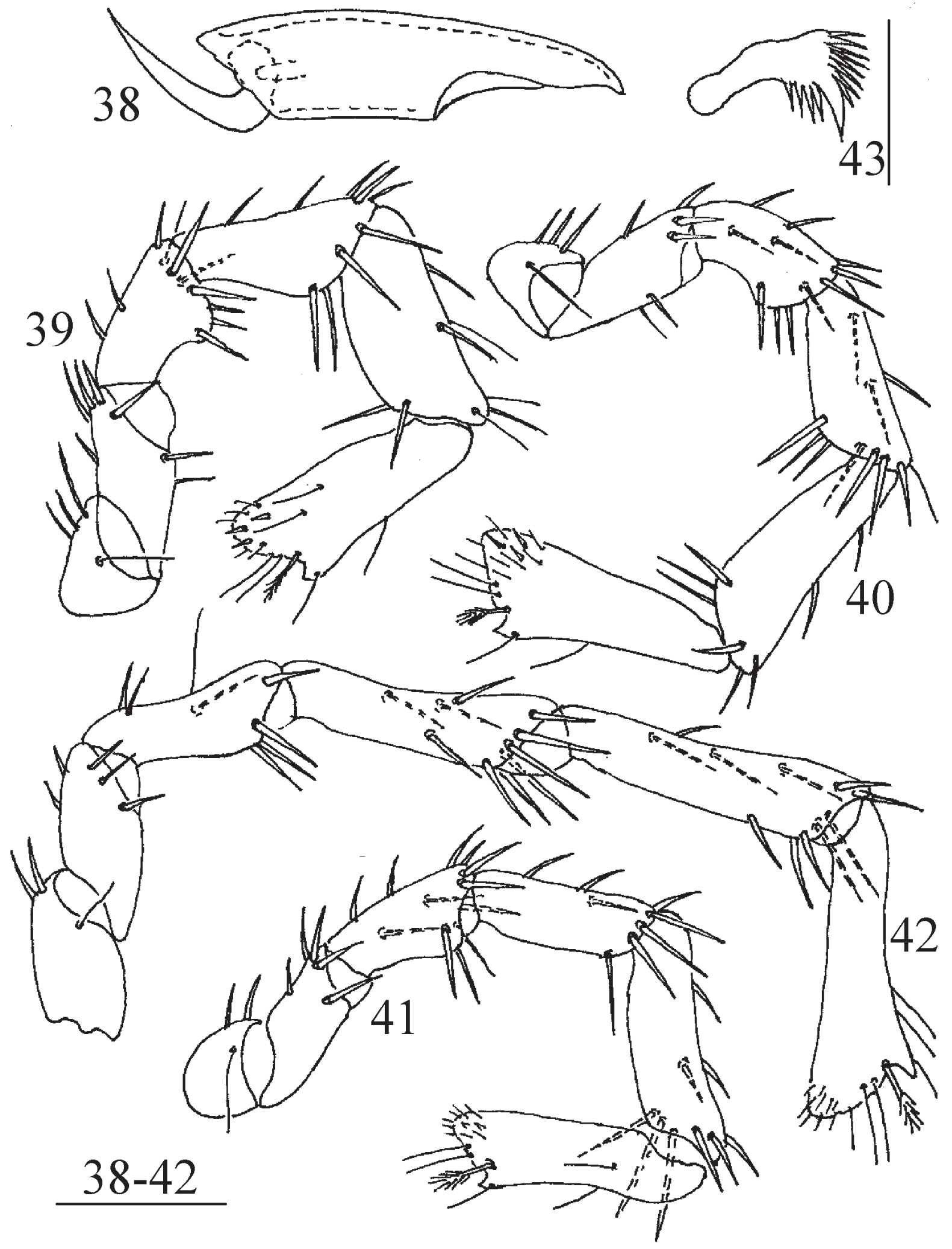

Figs. 38-43. Protzia primoryensis sp.n., male: 38 —chelicera; 39—leg I; 40—leg II; 41—leg III; 42—leg IV; 43—claw of leg IV. Scale bars: $38-42=100 \mu \mathrm{m}, 43=50 \mu \mathrm{m}$.

legs I-IV as shown in Figs. 39-42. Leg claws with 4-5 lateral and 7-8 medial clawlets (Fig. 43).
Male. Genital field (Fig. 34) with 10-12 pairs of acetabula and 5-15 pairs of setae. Ejaculatory complex (Fig. 35) proximal chamber large, with 
relatively large pointed anterior projection; proximal arms long, broadest basally, tapering gradually to apex; distal arms well developed and a little shorter than proximal arms only. $\mathrm{P}-3 \mathrm{~L} / \mathrm{H}$ ratio 0.88-0.94, P-2/P-4 L ratio 0.66-0.78.

Measurements $(\mathrm{n}=2)$. Idiosoma $\mathrm{L}$ about 775-975, W 300-345, coxal plates 1+2 L 155-190, W 125-150; coxal plates 3+4 L 175-200, W 130-140; capitulum L 175-210; cheliceral segments: base L 150-175, chela L 75-80; acetabula L 18-30, W 15-21, acetabula stalks L 12-15; ejaculatory complex L 108-115; pedipalp segments (P-1-5) L: 30-36, 65-72, 45-48, 84-108, 21-24; legs segments L: I-Leg-1-6: 60-75, 60-75, 85-100, 110-130, 125-150, 125-150; II-Leg-1-6: 60-65, 60-75, 85-100, 125-140, 130-165, 125-165; IIILeg-1-6: 55-65, 55-70, 75-90, 110-135, 130-150, 110-150; IV-Leg-1-6: 85-100, 70-85, 110-145, 150-185, 170-205, 135-165.

Female. Larger than male. Genital field with 9-14 pairs of acetabula and 4-6 pairs of setae. P-3 $\mathrm{L} / \mathrm{H}$ ratio $1.1, \mathrm{P}-2 / \mathrm{P}-4 \mathrm{~L}$ ratio $0.64-0.75$.

Measurements $(\mathrm{n}=9)$. Idiosoma L 900-1,150, coxal plates 1+2 L 175-200, W 150-200; coxal plates 3+4 L 185-200, W 135-140; capitulum L 210-235; cheliceral segments: base L 210-250, chela L 110-120; acetabula L 18-30, W 15-21, acetabula stalks L 12-21; pedipalp segments (P1-5) L: 35-37, 65-80, 65-68, 100-114, 24-30; leg segments L: I-Leg-1-6: 60-75, 75-80, 95100, 125-135, 135-150, 135-140; II-Leg-1-6: $60-75,70-75,90-100,130-140,155-175$, 135-145; III-Leg-1-6: 60-70, 60-65, 100-125, 135-140, 160-165, 145-150; IV-Leg-1-6: 100-125, 85-90, 135-150, 200-205, 210-220, $175-210$.

Differential diagnosis. The present species is similar to Protzia distincta Walter, 1922 in the shape of the coxal plates, genital field and pedipalps. Differences between the two species are found in the following characters (character states of $P$. distincta given in parenthesis; data from Gerecke 1996a, 1996b and Di Sabatino et al. 2010): genital field with 5-15 pairs of setae (14-23 pairs); P-2 with three setae, mediodistal seta long (five setae, two mediodistal setae short); P-2/P-4 L ratio $0.65-0.78(0.55-0.60)$; both sexes gonopore field smooth (male gonopore field with fine villi); ejaculatory complex proximal chamber with rather large pointed anterior projection, distal arms long (proximal chamber with short median protrusion, distal arms short).
Etymology. The species is named after the name of the region (Primorye Territory) where it was collected.

Habitat. Fluvial streams.

Distribution. Asia, Russia: Primorye Territory.

\section{Protzia rotunda Walter, 1908}

\author{
Calonyx cabardinicus Sokolow, 1940 \\ (Pešić 2005) \\ Figs. 44-51
}

I was unable to examine any $P$. rotunda specimens. The diagnosis of this species is based on reference data (Sokolow 1927, 1940; Gerecke 1996a, 1996b; Di Sabatino et al. 2010).

Diagnosis. Color red, frontal eye present, coxal plate I anterior tip projecting and densely covered by rather numerous strong setae, genital field with 8-10 pairs of acetabula, sclerotized bars present, $\mathrm{P}-2$ with five dorsal setae, mediodistal seta short, P-3 with two dorsodistal seta, leg claws with 3-4 lateral and 4-6 medial clawlets.

Description. Both sexes. Integument papillate, finely striated around genital field, frontal eye present. Coxal plate I anterior tip projecting and densely covered by strong setae; genital field with 8-10 pairs of acetabula on each side, flanked by a rather strong sclerotized bar, bearing 12-18 fine setae, these setae shorter in the anterior part, but elongated in the centre, where the sclerite is enlarged and extends between the acetabula and in the posterior part (Fig. 44). Anterior margin of coxal plate I straight, posterior margin of coxal plate II slightly concave, anterior coxal group with 29-39 setae on each side. Coxal plate III subrectangular, with straight medial margin, bearing seven relatively long anterior setae and a single short posteromedial seta; coxal plate IV subtriangular, with five rather long anterior and five short posterior setae (Fig. 45). All coxal plates with large pores in the centre and with fine pores laterally. Genital field (Fig. 46) with 8-10 pairs of acetabula, flanked on each side by a bar bearing 12-18 fine setae; these setae shorter in the anterior part, but elongated in the centre. Anterior acetabula almost roundish, caudal acetabula elongated (L/W ratio 1.1-1.5), on short stalks (L stalks/acetabula 0.6-0.9).

Capitulum (Fig. 47) dorsoventrally flattened, with weakly S-shaped ventral margin. Chelicera (Fig. 48) slender (L/H ratio 4.7-5.3), with small chela (basal segment/chela L 2.3-2.6). 


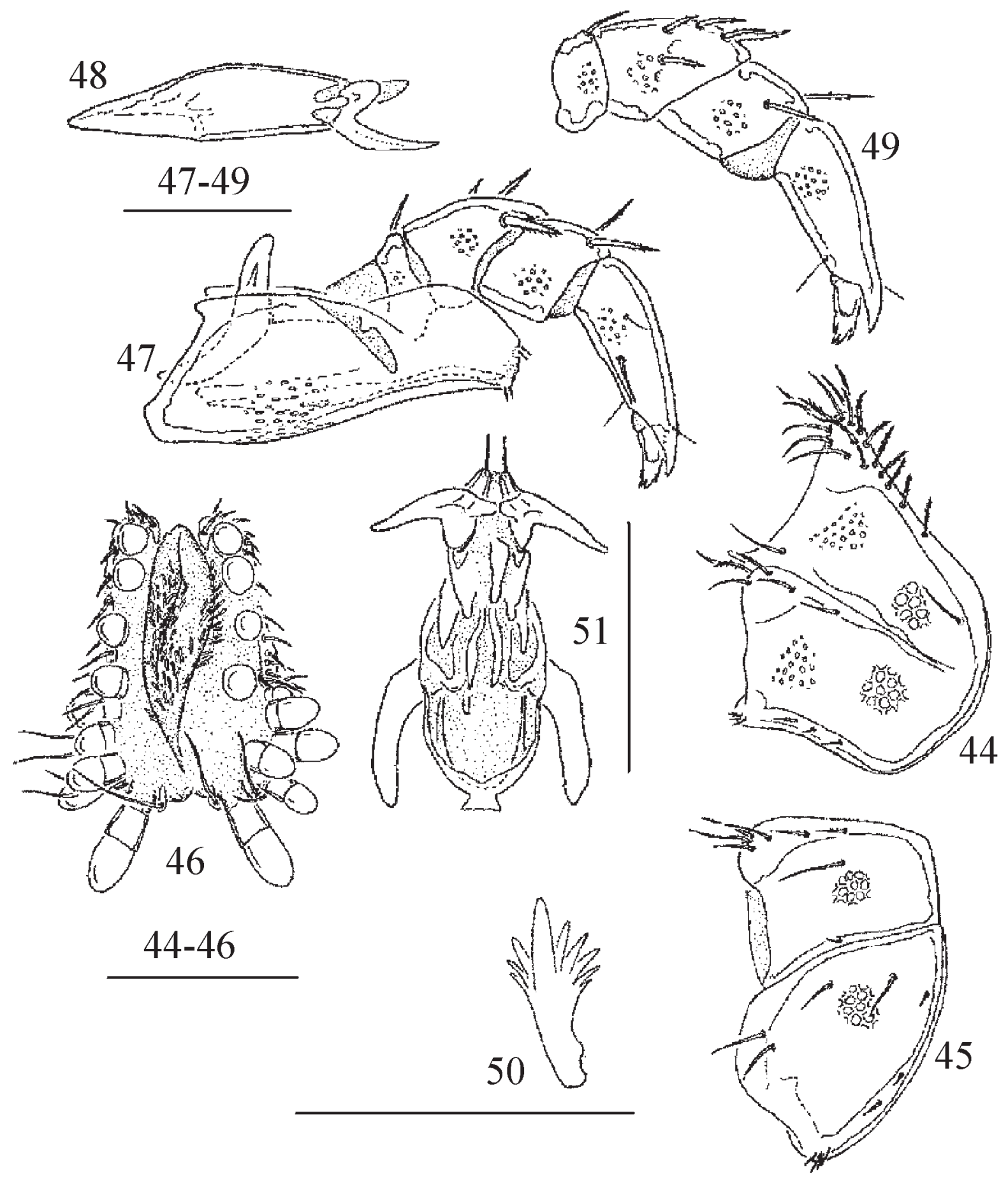

Figs. 44-51. Protzia rotunda Walter, 1908, male: 44 - coxal plates I+II; 45-coxal plates III+IV, 46-genital field; 47-capitulum, 48 - chelicera, 49-pedipalp, 50-leg claw, 51-ejaculatory complex (after Gerecke 1996b). Scale bars: $44-46,47-49,50,51=100 \mu \mathrm{m}$.

Pedipalp (Fig. 47 and 49) stout, P-1 with short dorsodistal seta; P-2 ventral margin short, straight, with four short dorsal setae and a strong, pennate mediodistal seta; P-3 ventral margin straight or slightly convex, with two dorsodistal setae; P-4 slender (L/H ratio 2.9-3.3), longer than P-2.

III/IV-Legs-3-5 with three to five slightly flattened dorsal setae. Leg claws with three to four lateral and four to six strongly diverging medial clawlets (Fig. 50).

Male. Gonopore field with fine villi (Fig. 46). Ejaculatory complex (Fig. 51) proximal chamber large, with small anterior projection with flat tip; proximal arms long, broadest basally, tapering gradually to apex; distal arms pointed and shorter than proximal ones. 


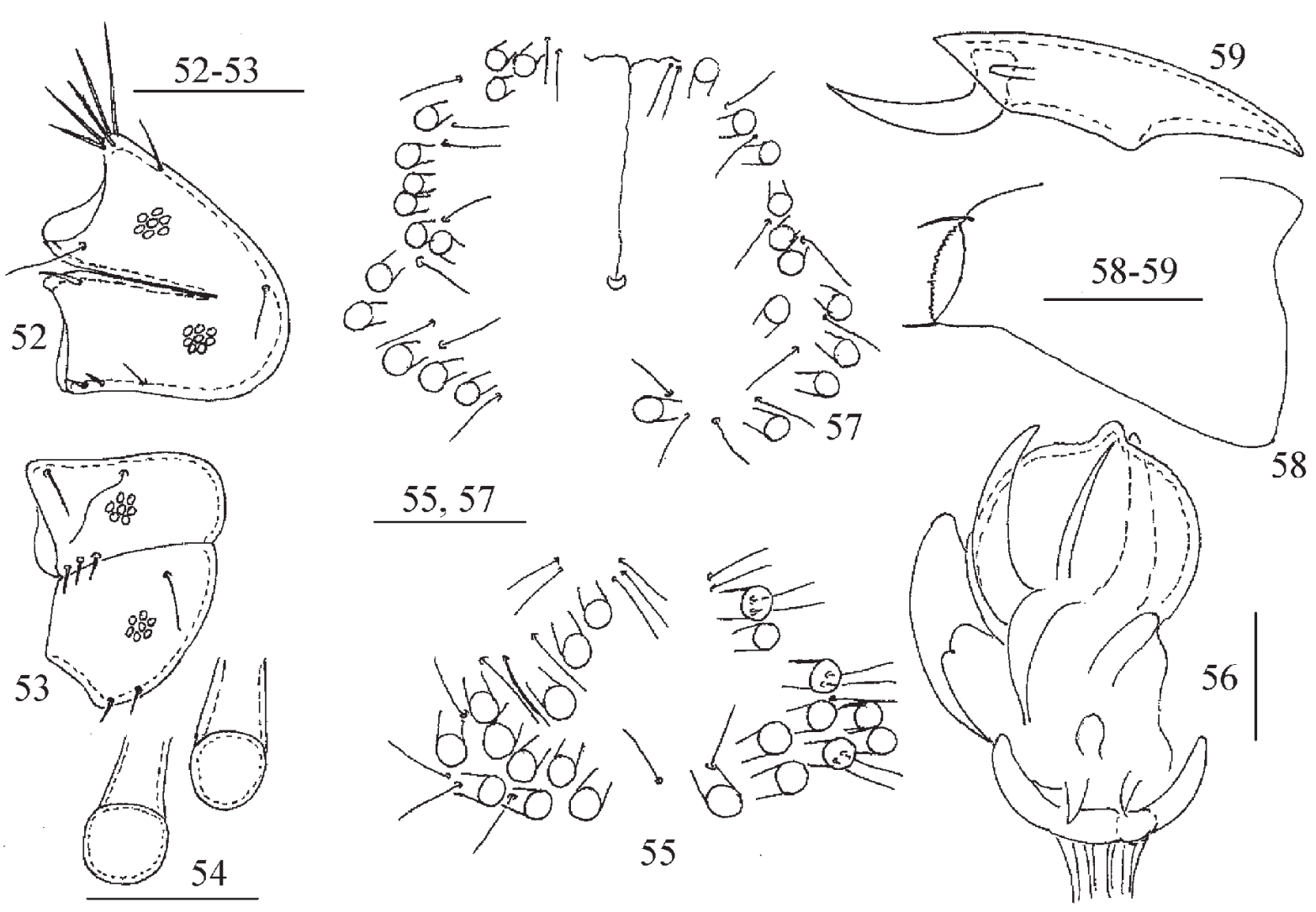

Figs. 52-59. Protzia uralensis sp.n., adults: 52 - coxal plates I+II; 53-coxal plates III+IV; 54-genital acetabula; 55, 57—genital field; 56 - ejaculatory complex; 58 - capitulum, lateral view; 59-chelicera; 52-56, 58-59-male; 57female. Scale bars: $52-53,55,57,58-59=100 \mu \mathrm{m} ; 54,56=50 \mu \mathrm{m}$.

Measurements. Idiosoma L about 640-860, W 450-580; capitulum L 190-210; rostrum L 54-67, chelicera L 221-241, ratio basal segment/chela L 2.3-2.6; ejaculatory complex L 150-180; coxal plates I+II L 224-243, W 157-180; coxal plates 3+4 L 175-200, W 130-140; caudal acetabula L 33, W 26, caudal acetabula stalks L 28; pedipalp segments (P-1-5) L: 23, 97, 52, 133, 37.5; Leg I-IV L 557, 596, 647, 797.

Female. Gonopore field smooth, genital field with 18-22 acetabula and 33-46 setae. Measurements. Idiosoma L 950-1,500, W 700-900; coxal plates I+II L 270-315, W 206-234; capitulum L 243-270, rostrum L 74-81; chelicera L 273-305; pedipalp (P-1-5) 353-400.

Distribution. Southern Europe, Asia Minor, Caucasus (Sokolow 1940; Gerecke 1996a; Di Sabatino et al. 2010).

\section{Protzia uralensis sp. $\mathrm{n}$.}

Figs. 52-65

Type material. Holotype: male, slide 9937 , Europe, Russia, Sverdlovsk Region, Visim Nature
Reserve, Maximikha River, $57^{\circ} 25^{\prime} 50.4^{\prime \prime} \mathrm{N} 59^{\circ} 46^{\prime}$ $12.8^{\prime \prime} \mathrm{E}$, depth $0.4 \mathrm{~m}$, ground: stones, 8 August 2016, leg. V. Stolbov. Paratype: one female, same locality and data as holotype.

Diagnosis. Color red, integument papillate, frontal eye absent, genital flaps not developed, P-2 with three short subequal dorsal setae and one long mediodistal seta; genital field with $10-15$ pairs of acetabula and 9-12 pairs of setae, all genital acetabula roundish and subequal in size; leg claws with 4-5 lateral and 7-8 medial clawlets.

Description. Both sexes. Color red, integument papillate, frontal eye not developed, dorsal and postventral idiosoma surface without muscle attachment sclerites. Coxal plates I+II (Fig. 52) with rounded medial and slightly concave posterior margins, coxal plate I with six unequal anterolateral setae, one medial and one posterolateral thin seta; coxal plate II with one anterolateral and three posterolateral setae. Suture line between coxal plates I+II incomplete, obliterated medially. Coxal plate III subrectangular, with slightly convex medial margin, bearing two anterior and one to three 


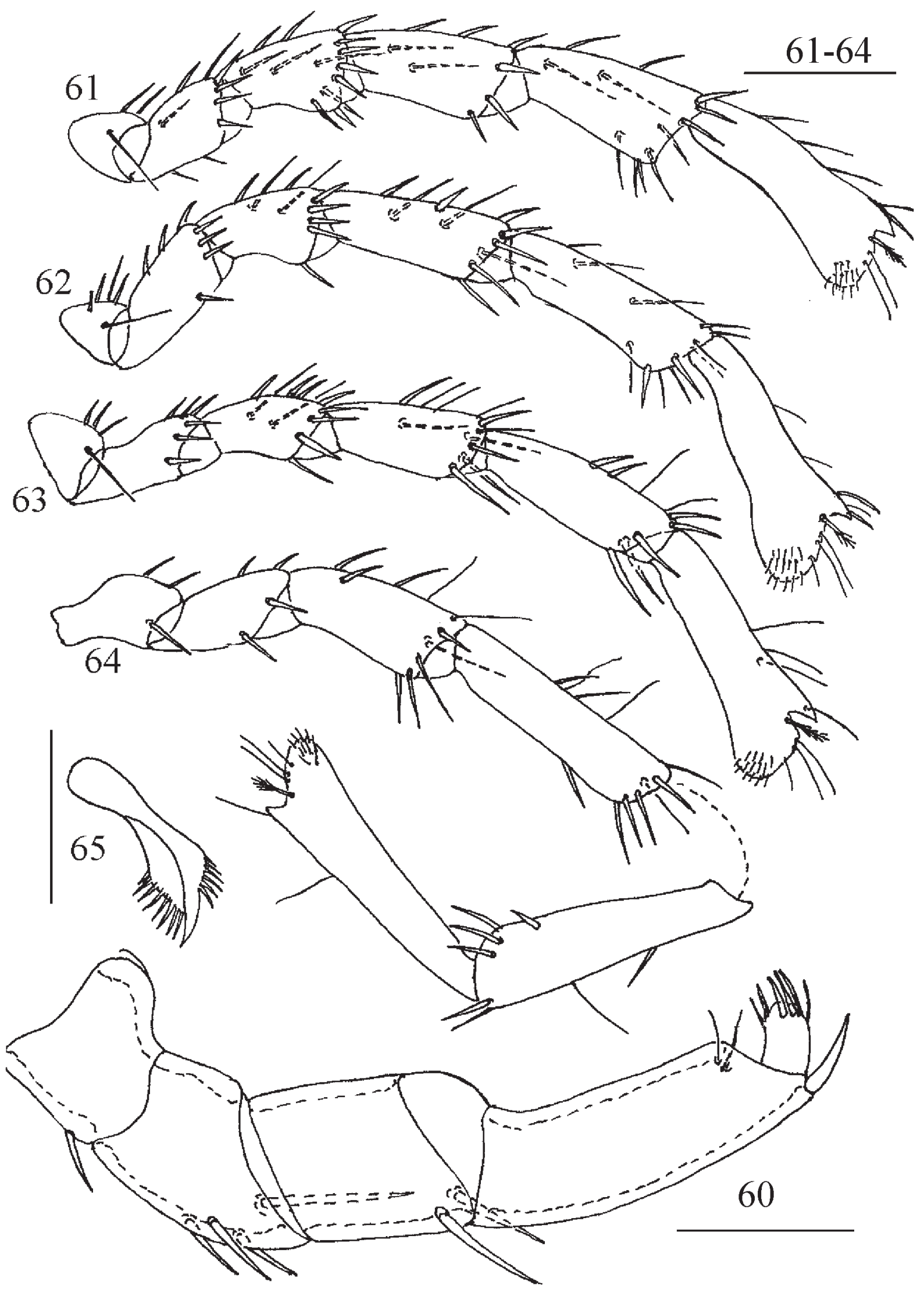

Figs. 60-65. Protzia uralensis sp.n., male: 60-pedipalp, 61-leg I, 62-leg II, 63-leg III, 64-leg IV, 65-leg claw. Scale bars: $60,65=50 \mu \mathrm{m} ; 61-64=100 \mu \mathrm{m}$. 
posterolateral setae; coxal plate IV subtriangular, with one rather long, thin anterior and two short posterior setae (Fig. 53). All coxal plates with rather large pores. Genital field smooth, genital flaps not developed. All acetabula roundish and subequal in size (Figs. 54, 55 and 57).

Capitulum (Fig. 58) with short rostrum. Basal segment of chelicera (Fig. 59) large, with equally convex dorsal margin, chela robust, basal segment/ chela L 2.0.

Pedipalp stout (Fig. 60): P-1 with short dorsodistal seta; P-2 ventral margin short almost straight, with three subequal dorsal setae and one long mediodistal seta; P-3 ventral margin straight $(\mathrm{L} / \mathrm{H}$ ratio 1.0$)$, with two dorsodistal setae; $\mathrm{P}-4$ longer than P-2 (P-2/P-4 L 0.75-0.88) with subparallel dorsal and ventral margin, with two ventrodistal setae, one fine dorsodistal seta and large thick pointed dorsodistal spine.

Legs very stout and densely covered with strong setae. Shape and arrangement of setae on legs I-IV as shown in Figs. 61-64. Leg claws with 4-6 lateral and 7-8 medial clawlets (Fig. 65).

Male. Genital field with 10-12 pairs acetabula and 10-12 pairs setae (Fig. 55). Ejaculatory complex (Fig. 56) proximal chamber large; proximal arms massive, pointed, broadest basally, tapering gradually to apex; distal arms relatively slightly developed with obtuse tips.

Measurements $(\mathrm{n}=1)$. Idiosoma $\mathrm{L}$ about 810 , coxal; plates I+II L 145, W 150, coxal; plates III+IV L 150, W 120; capitulum L 240, rostrum L 55; cheliceral segments: base L 160, chela L 85; acetabula D 18-24, acetabula stalks L 18-27; ejaculatory complex L 175; pedipalp segments (P-1-5) L: 36, 72, 48-54, 96, 27; leg segments L: I-Leg-1-6: 60, 75, 85, 125, 140, 150; II-Leg-1-6: 60, 75, 100, 135, 150, 180; III-Leg-1-6: 60, 75, 100, 135, 160, 160; IV-Leg-1-6: 85, 75, 125, 175, 200, 185.

Female. Larger than male. Genital field with 12-15 pairs acetabula and 9-12 pairs setae (Fig. 57).

Measurements $(\mathrm{n}=1)$. Idiosoma $\mathrm{L}$ about 1,000 ; coxal plates I+II L 180, W 150; coxal plates III+IV 170, W 120; capitulum L 205, rostrum L 35; cheliceral segments: base L 205, chela L 100; acetabula D 21-25, acetabula stalks L 21-27; pedipalp segments (P-1-5) L: 36, 90, 57, 110, 30; leg segments L: I-Leg-1-6: 60, 100, 90, 125, 150, 160; II-Leg-1-6: 60, 110, 100, 135, 160, 165; IIILeg-1-6: 60, 85, 105, 150, 175, 160; IV-Leg-1-6: 110, 100, 135, 200, 210, 200.

Differential diagnosis. The present species is similar to Protzia buryatica sp.n. in the shape of the coxal plates and the structure of the genital field. Differences between the two species are found in the following characters (character states of P. buryatica sp.n. given in parentheses), capitulum long, male L 240 (relatively short L 190), genital field with 9-12 pairs of setae (15-20 pairs), P-2 with four setae (five setae), P-3 ventral margin straight (convex), leg claws with 7-8 medial clawlets (with 11-13 medial clawlets).

Etymology. The species is named after the name of the region (Ural) where it was found.

Habitat. Fluvial streams.

Distribution. Europe, Russia: Ural region.

\section{Key to species of the genus Protzia in Ruissia}

1. All genital acetabula roundish and subequal in size

- Posterior acetabula elongated ........................... 3

2. Leg claws with 11-13 medial clawlets (Fig. 12), P-2 with five setae (Fig. 7)........P. buryatica sp.n. - Leg claws with 7-8 medial clawlets (Fig. 65), P-2 with four setae (Fig. 60) .... P. uralensis sp.n. 3. P-3 with single dorsodistal seta, Fig. 26

P. eximia

P-3 with two dorsodistal setae 4

4. P-2 with five setae (Fig. 49), coxal plates I+II with 29-37 setae (Fig. 44), genital bars present ... $P$. rotunda

- P-2 with three setae, coxal plates I+II with a few setae $(<20)$, genital bars absent. 5 5. Gonopore field with fine villi, Fig. 15

P. caucasica

— Gonopore field smooth, Fig. 36

P. primoryensis sp.n.

\section{ACKNOWLEDGEMENTS}

This research was performed as part of a state assignment of the Federal Agency of Science Organizations (FASO), Russia (project № 0122-20140007). The author expresses his deep gratitude to V.A. Stolbov and T.S. Vshivkova for collecting the material and to the anonymous referees for reviewing the manuscript.

\section{REFERENCES}

Di Sabatino, A., Gerecke, R., Gledhill, T. and Smit, H. 2010. 8. Acari: Hydrachnidia II. In: R. Gerecke (Ed.). Süßwasserfauna von Mitteleuropa, 7/2-2. Spectrum Akademischer Verlag Heidelberg, pp. 1-429.

Gerecke, R. 1996a. Untersuchungen über Wassermilben der Familie Hydryphantidae (Acari, Actinedida) in 
P. V. Tuzovsky

der Westpalaearktis, I. Beitrag zur Kenntnis der Gattung Protzia Piersig, 1896 (Acari, Actinedida, Hydryphantidae). Archiv für Hydrobiologie, Supplementband, 77(3/4): 271-336.

Gerecke, R. 1996b. Untersuchungen über Wassermilben der Familie Hydryphantidae (Acari, Actinedida) in der Westpalaearktis, II. Die Wassermilben der Familie Hydryphantidae Piersig, 1896 in den Mittelmeerländer. Archiv für Hydrobiologie, Supplementband, $77(3 / 4): 337-521$.
Pešić, V. 2005. Water mites of the genus Protzia Piersig, 1896 (Acari, Hydrachnidia: Hydryphantidae) from Iran. Zootaxa, 1019: 53-64.

Sokolow, I.I. 1927. Beitrag zur Kenntnis der Hydracarinenfauna vom Kaukasus. Travaux de la Station Biologique de Caucase du Nord, Gorsky Institut Agronomique, Vladicaucase, 5(2): 43-72.

Sokolow, I.I. 1940. [Hydracarina. Part I: Hydrachnellae]. Fauna of the USSR, Paukoobraznye 5(2). Nauka, Moscow-Leningrad. 511 pp. [In Russian] 